\title{
Average Marginal Tax Rates from Social Security and the Individual Income Tax
}

\section{Citation}

Barro, Robert J., and Chaipat Sahasakul. 1986. Average marginal tax rates from social security and the individual income tax. Journal of Business 59(4): 555-566.

\section{Published Version}

doi:10.1086/296354

\section{Permanent link}

http://nrs.harvard.edu/urn-3:HUL.InstRepos:3451298

\section{Terms of Use}

This article was downloaded from Harvard University's DASH repository, and is made available under the terms and conditions applicable to Other Posted Material, as set forth at http:// nrs.harvard.edu/urn-3:HUL.InstRepos:dash.current.terms-of-use\#LAA

\section{Share Your Story}

The Harvard community has made this article openly available.

Please share how this access benefits you. Submit a story.

Accessibility 


\section{Average Marginal Tax Rates from Social Security and the Individual Income Tax ${ }^{*}$}

In our previous paper (Barro and Sahasakul 1983) we provided estimates of average marginal tax rates from the federal individual income tax for 1916-80. Now we extend these figures to 1983 and supplement them to include the social security tax on labor earnings. With this addition, in 1983 the included taxes constitute $73 \%$ of federal and $45 \%$ of total government receipts. If some nontax items are excluded, the values are $78 \%$ and $53 \%$, respectively. ${ }^{1}$

In the main, the social security levy is a flatrate tax, paid partly by workers, partly by employers, and partly by self-employed persons. The computation of average marginal tax rates is simpler than in the case of the federal income tax, which has a graduated-rate structure and allows for numerous deductions from taxable income. The main complications that arise for the social security tax are the following. (a) For workers and self-employed persons with earnings above a ceiling value the marginal tax rate is nil; (b) the tax applies only to labor earnings (and to earnings from self-employment) rather than to total income; (c) the employer and employee

* This research was supported by the National Science Foundation. We appreciate the data that were provided on income taxes by Dan Holik and on social security by Anthony Pellechio and Wayne Long.

1. The data are from U.S. Survey of Current Business, March 1986.

(Journal of Business, 1986, vol. 59, no. 4, pt. 1)

(c) 1986 by The University of Chicago. All rights reserved. 0021-9398/86/5904-0002\$01.50
We extend previous estimates of the average marginal tax rate from the federal individual income tax to include social security. Our computations consider the tax rates on employers, employees, and the self-employed; the income that accrues to persons with earnings below the ceiling; and the effective deductibility of employers' social security contributions from workers' taxable income. The net effect of social security on the average marginal tax rate is below .02 until 1966 but then rises to .03 in 1968, .04 in 1973, .05 in $1974, .06$ in 1979 , and .07 in 1982 . 
parts of the tax differ because the employer's payments are not counted as part of the employee's taxable income; and $(d)$ an individual's future social security benefits depend positively on that person's history of contributions. The last element reduces the effective tax rate that an individual faces. In fact, Gordon (1982) argues that this consideration is important for people who are close to retirement age. Generally, the inclusion of this effect would require forecasts of benefit schedules as well as survival probabilities. It would also be necessary to include various complexities of the social security law, such as the declining marginal effect of past covered earnings on benefits, the exclusion of some years of earnings from the formula, and the treatment of spouses and dependents. In any event, our subsequent calculations do not take account of the effects of social security contributions on future benefits. Thus, by including only the tax aspects of these "contributions," we somewhat overstate the effective marginal tax rates from the social security program.

\section{Theoretical Considerations}

Let $s_{f}$ be the social security tax rate (marginal and average) paid by a firm on workers' earnings. If profits are taxed at the rate $\tau_{\pi}$, then the firm's after-tax profits are

$$
\pi=\left(1-\tau_{\pi}\right)\left[F(L)-w L\left(1+s_{f}\right)\right],
$$

where $L$ is the quantity of labor input, $w$ is the real wage rate, and $F(L)$ is the production function. Maximization of profit implies

$$
F^{\prime}=w\left(1+s_{f}\right),
$$

where $F^{\prime}$ is labor's marginal product.

The representative worker's total real income, $Y$, equals $w L+I$, where $I$ is nonlabor income. As in our previous paper, this income is spent on consumption, $C$, or on income taxes, $T .^{2}$ In addition, there is now the worker's social security $\operatorname{tax}, s_{e} \cdot w L$, where $s_{e}$ is the employee's (marginal and average) contribution rate. Thus we have

$$
Y=w L+I=C+T+s_{e}(w L) .
$$

As before, income taxes, $T$, depend on taxable income, $Y-D$, where $D$ is a broad concept of deductions. If utility depends positively on consumption and negatively on work, then the first-order condition for

2. For present purposes it is unnecessary for us to consider two categories of consumption-depending on the treatment by the tax law-as we did in the earlier paper. We also do not allow here for efforts aimed at avoiding income taxes. 
maximizing utility can be written as

$$
\frac{-\partial U / \partial L}{\partial U / \partial C}=w\left(1-T^{\prime}-s_{e}\right)
$$

where $T^{\prime}$ is the marginal income-tax rate.

Substituting for $w$ from equation (2) into equation (4) implies

$$
\frac{-\partial U / \partial L}{\partial U / \partial C}=\frac{F^{\prime}\left(1-T^{\prime}-s_{e}\right)}{1+s_{f}} .
$$

Thus equation (5) shows how the tax system creates a positive wedge between labor's marginal product, $F^{\prime}$, and the utility rate of substitution between consumption and leisure, $-(\partial U / \partial L) /(\partial U / \partial C)$.

Let $\tau$ be the overall effective marginal tax rate on labor's marginal product, $F^{\prime}$. Then equation (5) implies

$$
1-\tau=\frac{1-T^{\prime}-s_{e}}{1+s_{f}}
$$

or

$$
\tau=\frac{1}{1+s_{f}}\left(s_{f}+s_{e}+T^{\prime}\right)
$$

Thus the tax system effectively deflates labor's marginal product, $F^{\prime}$, by the factor $1+s_{f}$ (see eq. [2]) and then applies the marginal tax rate, $s_{f}+s_{e}+T^{\prime}{ }^{3}$ If the social security tax is not purely a flat-rate levy (because of the ceiling on taxable earnings in the U.S. system), then we can interpret $s_{f}$ and $s_{e}$ in equation (6) as the marginal social security tax rates.

For self-employed persons the formula is simpler; namely, if $s_{s}$ is the marginal contribution rate to social security, then the effective marginal tax rate, $\tau_{s}$, is ${ }^{4}$

$$
\tau_{s}=s_{s}+T^{\prime}
$$

Previously, we calculated weighted averages, $\bar{T}^{\prime}$, of the marginal income tax rates, $T^{\prime}$. We weighted either by adjusted gross income or by numbers of returns, and we computed arithmetic and geometric averages. Here we consider only the series that we focused on earlier, which is the arithmetic average weighted by adjusted gross income.

3. Note that $\tau$ does not depend solely on the sum $s_{f}+s_{e}$. That is because, unlike the worker's payments, the employer's payments are not part of the worker's tax base.

4. If the marginal tax rates, $T^{\prime}$, are equal, then the equation of $\tau_{s}$ from (7) to $\tau$ in (6) requires $s_{s}$ to be less than $s_{f}+s_{e}$, as was true in the United States until 1984. For example, if $T^{\prime}=.3$ and $s_{f}=s_{e}=.067$ (the value for 1982), then the equalizing value for $s_{s}$ is .017. The actual value of $s_{s}$ for 1982 was .0935 . The social security law passed in 1983 and effective in 1984 sets the self-employed rate equal to the sum $s_{f}+s_{e}$ but provides for some offsetting income tax credits. 
Equations (6)-(7) tell us the necessary extensions to go from the previous measures, $\bar{T}^{\prime}$, to weighted averages, $\bar{\tau}$, that include the social security tax; namely, ${ }^{5}$

$$
\bar{\tau} \approx \bar{T}^{\prime}+\Omega_{1}\left(\frac{s_{f}+s_{e}}{1+s_{f}}\right)+\Omega_{2} \cdot s_{s}-\Omega_{1} \cdot s_{f} \cdot \bar{T}^{\prime \prime},
$$

where $s_{f}, s_{e}$, and $s_{s}$ are now the social security contribution rates for persons with earnings below the taxable ceiling; ${ }^{6} \Omega_{1}$ is the ratio to aggregate adjusted gross income of the wage and salary income of workers with earnings below the ceiling; $\Omega_{2}$ is the corresponding ratio for self-employed persons; and $\bar{T}^{\prime \prime}$ is the (weighted) average marginal tax rate for workers with earnings below the ceiling.

\section{Computations of Tax Rates}

Table 1 shows the salaries and wages (col. 1) and self-employment income (col. 3) that accrue in each year to persons with earnings below the ceiling. (In col. 4 the table shows the dollar value of the ceiling for each year.) These data, combined with values of aggregate adjusted gross income, allow us to calculate the weights $\Omega_{1}$ and $\Omega_{2}$, which appear in equation (8). These weights are in columns 5-6 of table 1 .

For subsequent purposes the important variable is $\Omega_{1}$, the ratio to adjusted gross income of the salaries and wages of persons below the ceiling. This ratio can be divided into two parts-first, the ratio of salaries and wages of persons below the ceiling to the aggregate of salaries and wages (col. 2 of table 1) and, second, the ratio of aggregate salaries and wages to aggregate adjusted gross income. The latter ratio is highly stable about its mean value of .84 . Hence $\Omega_{1}$ fluctuates mainly because of changes in the fraction of overall salaries and wages that accrue to persons below the ceiling. This fraction depends in turn on the ceiling earnings for social security in relation to the distribution of nominal earnings in the economy. For example, the decrease in $\Omega_{1}$ from .46 in 1937 to .24 in 1965 corresponds to a decline in the ratio of salaries and wages for persons below the ceiling to total salaries and wages from .57 to .29 . This behavior reflects the relatively slow rise in the dollar ceiling on earnings, which increased from $\$ 3,000$ in 1937 to only $\$ 4,800$ in 1965 . However, the ceiling has advanced rapidly since 1965 , reaching $\$ 35,700$ in 1983 . Correspondingly, the ratio of salaries and wages for persons below the ceiling to total salaries and wages went from .29 in 1965 to .68 in 1983 . This change led to an increase in $\Omega_{1}$ from .24 in 1965 to .57 in 1983 .

5. To get the last term we approximate $T^{\prime} /\left(1+s_{f}\right) \approx T^{\prime}\left(1-s_{f}\right)$ in (6). This approximation is satisfactory for our data sample.

6. Note that the social security levy is a flat-rate tax in this range. 
The values for $s_{f}=s_{e}$ and $s_{s}$ for each year also appear in table 1 . (These values are nonzero only since the start of the social security program in 1937.) Using these numbers we can calculate the second term, $\Omega_{1}\left(s_{f}+s_{e}\right) / 1+s_{f}$, and the third term, $\Omega_{2} \cdot s_{s}$, on the right side of equation (8). The results appear in columns 2-3 of table 2 .

It is more complicated to calculate the final term of equation (8), which depends on the average marginal tax rate $\bar{T}^{\prime \prime}$ for workers with earnings below the ceiling. From the IRS's Statistics of Income, Individual Tax Returns for each year, we approximated $\bar{T}^{\prime \prime}$ by using the marginal tax rates and associated values of adjusted gross income for the following filing units. First, we take all returns from income classes for which the average of salaries and wages per return is below the ceiling value. (For example, for 1980, when the ceiling on earnings is $\$ 25,900$, we go up to an adjusted gross income per return of $\$ 30,000$.) We then include enough additional joint returns from income classes where the average of salaries and wages per return is above the ceiling so as to exhaust the known total of salaries and wages that accrues to persons with earnings below the ceiling. However, we carry out this calculation by using the lowest possible income classes; that is, we assume that low numbers for individuals' salaries and wages correspond to low numbers for adjusted gross income per return. There is some approximation here since some of the low values for salaries and wages may come from either multiearner families or families with high nonlabor income, which would have high marginal tax rates. But some experimentation indicates that the potential error is quantitatively unimportant. Column 4 of table 2 shows the resulting calculation for the final term, $-\Omega_{1} s_{f} \bar{T}^{\prime \prime}$, in equation (8). Note that this term, which reflects the exclusion of firms' social security payments from workers' taxable income, is always below .01 in magnitude.

Our previous estimates of the average marginal tax rate when weighted by adjusted gross income, $\bar{T}^{\prime}$, appear in column 1 of table 2 . With the availability of more recent data we can now extend the series from 1980 to 1983 . For 1981, where the Reagan tax cut applied only to a small extent, the effects of bracket creep actually raised the average marginal tax rate, $\bar{T}^{\prime}$, from $30.4 \%$ in 1980 to $31.3 \%$ in 1981 . But then there was a substantial drop to $29.3 \%$ in 1982 and $27.2 \%$ in 1983 . The decline in the average marginal tax rate by 4.1 percentage points from 1981 to 1983 was much larger than that (2.6 percentage points) for the Kennedy-Johnson tax cut in 1964 . When later data are available, it will be interesting to see the extent to which the average marginal tax rates declined further in 1983 and 1984.

The overall modifications to incorporate the social security tax-the sum of columns 2-4 in table 2-appear in column 5 of the table (labeled SS). Then the sum of columns 1 and 5 is the average marginal tax rate, $\bar{\tau}$, from the federal individual income tax and the social security tax. 


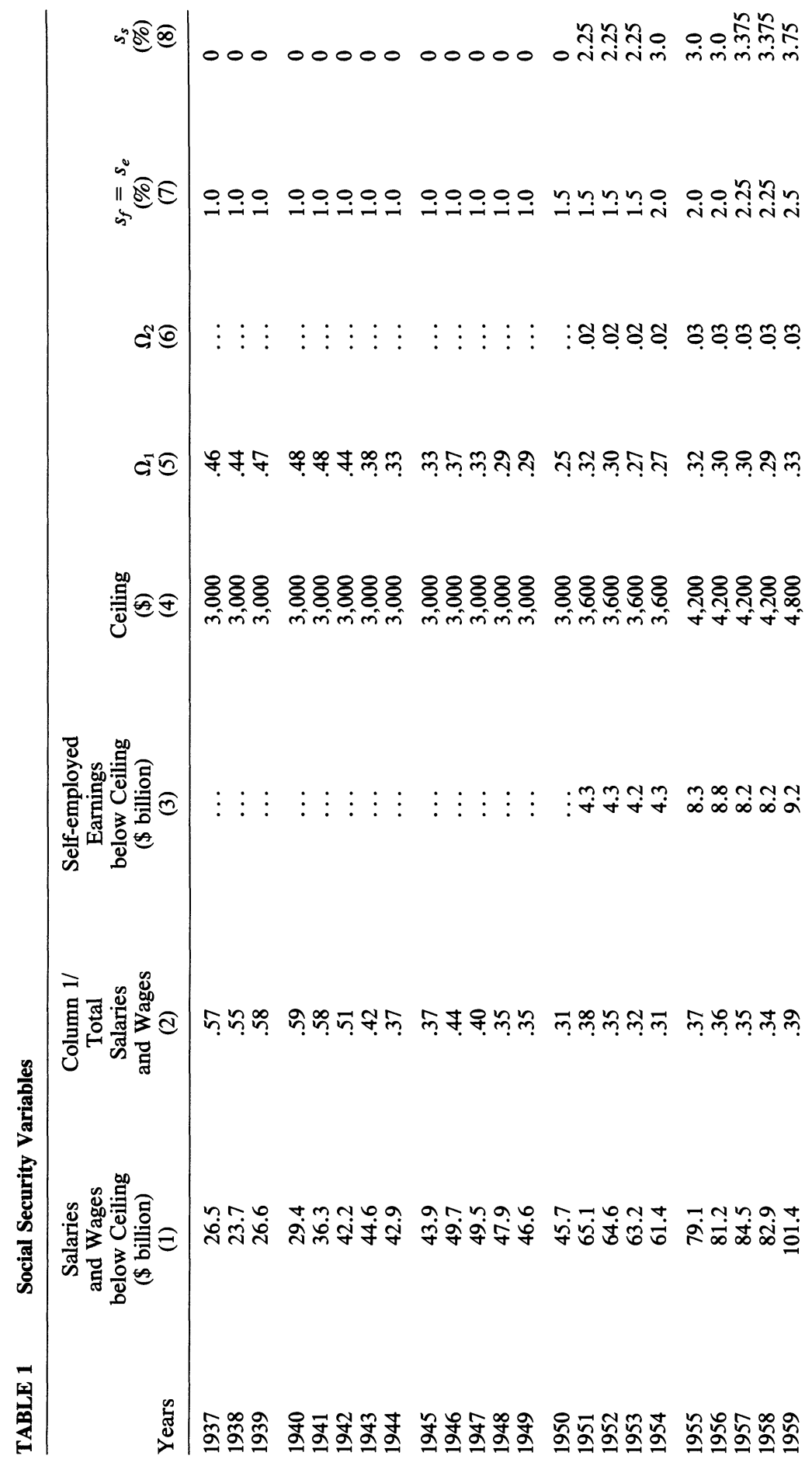




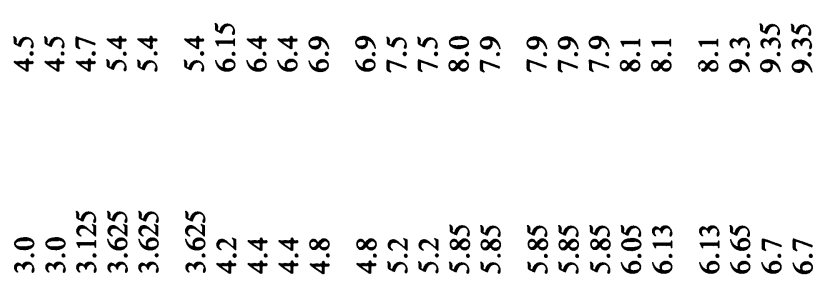

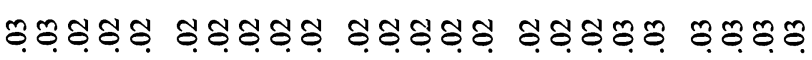

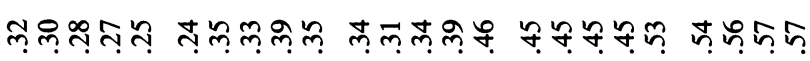

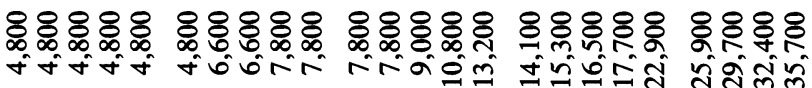

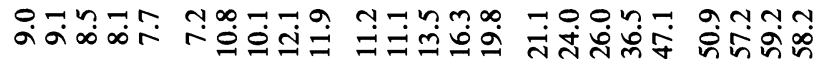

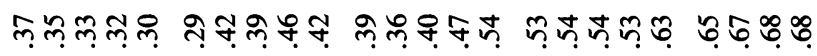

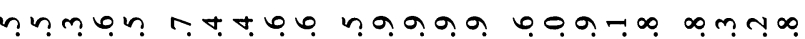

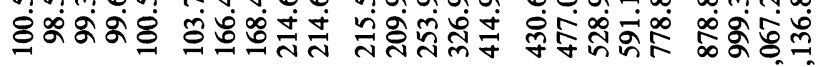

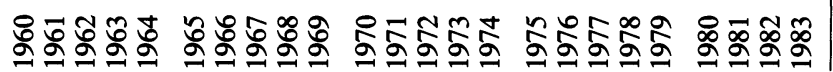

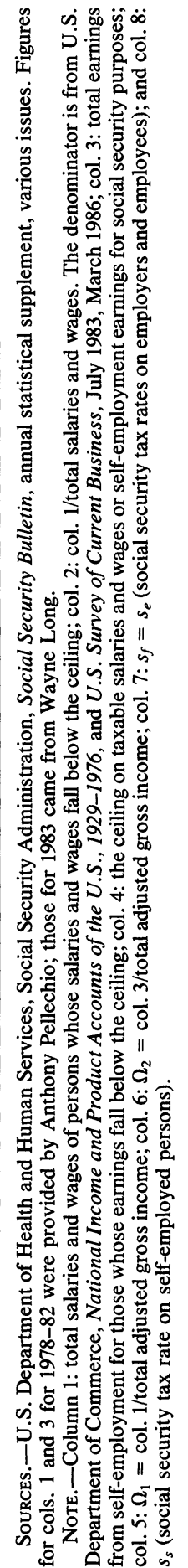


TABLE 2 Average Marginal Tax Rates

\begin{tabular}{|c|c|c|c|c|c|c|}
\hline Years & $\begin{array}{l}\bar{T}^{\prime} \\
(1)\end{array}$ & $\Omega_{1} \cdot \frac{s_{f}+s_{e}}{1+s_{f}}$ & $\begin{array}{l}\Omega_{2} \cdot s_{s} \\
\quad(3)\end{array}$ & $\begin{array}{c}-\Omega_{1} \cdot s_{f} \cdot \bar{T}^{\prime \prime} \\
\text { (4) }\end{array}$ & $\begin{array}{l}\text { SS } \\
(5)\end{array}$ & $\begin{array}{c}\bar{\tau} \\
(6)\end{array}$ \\
\hline 1916 & .012 & $\ldots$ & $\ldots$ & $\ldots$ & $\ldots$ & .012 \\
\hline 1917 & .037 & $\ldots$ & ... & $\ldots$ & $\ldots$ & .037 \\
\hline 1918 & .054 & $\ldots$ & $\ldots$ & $\ldots$ & $\ldots$ & .054 \\
\hline 1919 & .052 & $\ldots$ & $\cdots$ & $\ldots$ & $\ldots$ & .052 \\
\hline 1920 & .046 & $\ldots$ & $\ldots$ & $\ldots$ & $\ldots$ & .046 \\
\hline 1921 & .042 & $\ldots$ & $\ldots$ & $\ldots$ & $\ldots$ & .042 \\
\hline 1922 & .046 & $\ldots$ & $\ldots$ & $\ldots$ & $\ldots$ & .046 \\
\hline 1923 & .033 & ... & $\ldots$ & $\ldots$ & $\ldots$ & .033 \\
\hline 1924 & .035 & $\ldots$ & .. & $\ldots$ & $\ldots$ & .035 \\
\hline 1925 & .030 & $\ldots$ & $\ldots$ & $\ldots$ & $\ldots$ & .030 \\
\hline 1926 & .028 & $\ldots$ & $\ldots$ & $\ldots$ & $\ldots$ & .028 \\
\hline 1927 & .032 & $\ldots$ & $\ldots$ & $\ldots$ & $\ldots$ & .032 \\
\hline 1928 & .041 & $\ldots$ & $\ldots$ & $\ldots$ & $\ldots$ & .041 \\
\hline 1929 & .035 & ... & ... & $\ldots$ & $\ldots$ & .035 \\
\hline 1930 & .023 & $\ldots$ & $\ldots$ & $\ldots$ & $\ldots$ & .023 \\
\hline 1931 & .017 & $\ldots$ & $\ldots$ & $\ldots$ & $\ldots$ & .017 \\
\hline 1932 & .029 & $\ldots$ & $\ldots$ & $\ldots$ & $\ldots$ & .029 \\
\hline 1933 & .031 & $\ldots$ & $\ldots$ & $\ldots$ & $\ldots$ & .031 \\
\hline 1934 & .034 & $\ldots$ & $\ldots$ & $\ldots$ & $\ldots$ & .034 \\
\hline 1935 & .038 & $\ldots$ & $\ldots$ & $\ldots$ & $\ldots$ & .038 \\
\hline 1936 & .052 & & $\ldots$ & $\ldots$ & & .052 \\
\hline 1937 & .046 & .009 & 0 & -.000 & .009 & .055 \\
\hline 1938 & .034 & .009 & 0 & -.000 & .009 & .043 \\
\hline 1939 & .038 & .009 & 0 & -.000 & .009 & .047 \\
\hline 1940 & .056 & .010 & 0 & -.000 & .009 & .065 \\
\hline 1941 & .113 & .010 & 0 & -.000 & .009 & .123 \\
\hline 1942 & .192 & .009 & 0 & -.001 & .008 & .200 \\
\hline 1943 & .209 & .007 & 0 & -.001 & .007 & .216 \\
\hline 1944 & .252 & .007 & 0 & -.001 & .006 & .258 \\
\hline 1945 & .257 & .006 & 0 & -.001 & .006 & .262 \\
\hline 1946 & .226 & .007 & 0 & -.000 & .007 & .233 \\
\hline 1947 & .226 & .006 & 0 & -.000 & .006 & .232 \\
\hline 1948 & .180 & .006 & 0 & -.000 & .006 & .185 \\
\hline 1949 & .175 & .006 & 0 & -.000 & .005 & .180 \\
\hline 1950 & .196 & .008 & 0 & -.000 & .007 & .202 \\
\hline 1951 & .231 & .010 & .000 & -.001 & .009 & .240 \\
\hline 1952 & .251 & .009 & .000 & -.001 & .008 & .259 \\
\hline 1953 & .249 & .008 & .000 & -.001 & .008 & .257 \\
\hline 1954 & .222 & .010 & .001 & -.001 & .010 & .231 \\
\hline 1955 & .228 & .012 & .001 & -.001 & .012 & .240 \\
\hline 1956 & .232 & .012 & .001 & -.001 & .012 & .243 \\
\hline 1957 & .232 & .013 & .001 & -.001 & .013 & .245 \\
\hline 1958 & .229 & .013 & .001 & -.001 & .013 & .242 \\
\hline 1959 & .236 & .016 & .001 & -.001 & .016 & .252 \\
\hline 1960 & .234 & .018 & .001 & -.002 & .018 & .253 \\
\hline 1961 & .240 & .017 & .001 & -.002 & .017 & .257 \\
\hline 1962 & .244 & .017 & .001 & -.002 & .017 & .260 \\
\hline 1963 & .247 & .019 & .001 & -.002 & .018 & .265 \\
\hline 1964 & .221 & .018 & .001 & -.001 & .017 & .238 \\
\hline
\end{tabular}


TABLE 2 (Continued)

\begin{tabular}{lcccccc}
\hline & $\Omega_{1} \cdot \frac{s_{f}+s_{e}}{1+s_{f}}$ & $\Omega_{2} \cdot s_{1}$ & $-\Omega_{1} \cdot s_{f} \cdot \bar{T}^{\prime \prime}$ & $\mathrm{SS}$ & $\bar{\tau}$ \\
Years & $(1)$ & $(2)$ & $(3)$ & $(4)$ & $(5)$ & $(6)$ \\
\hline 1965 & .212 & .017 & .001 & -.001 & .016 & .229 \\
1966 & .217 & .028 & .001 & -.002 & .028 & .245 \\
1967 & .223 & .028 & .001 & -.002 & .027 & .250 \\
1968 & .252 & .032 & .001 & -.003 & .031 & .283 \\
1969 & .261 & .032 & .001 & -.003 & .031 & .292 \\
1970 & .243 & .031 & .001 & -.003 & .029 & .272 \\
1971 & .239 & .031 & .001 & -.003 & .029 & .268 \\
1972 & .242 & .034 & .001 & -.003 & .032 & .274 \\
1973 & .250 & .044 & .002 & -.004 & .041 & .291 \\
1974 & .257 & .050 & .002 & -.004 & .048 & .305 \\
1975 & .263 & .050 & .002 & -.005 & .047 & .310 \\
1976 & .273 & .050 & .002 & -.005 & .046 & .319 \\
1977 & .281 & .050 & .002 & -.005 & .047 & .328 \\
1978 & .310 & .052 & .002 & -.006 & .047 & .357 \\
1979 & .289 & .061 & .003 & -.007 & .057 & .346 \\
1980 & .304 & .062 & .002 & -.008 & .057 & .362 \\
1981 & .313 & .070 & .003 & -.010 & .063 & .376 \\
1982 & .293 & .071 & .003 & -.008 & .066 & .359 \\
1983 & .272 & .072 & .003 & -.008 & .067 & .339 \\
\hline
\end{tabular}

Note. $-\bar{T}^{\prime}$ is the average marginal income tax rate, weighted by adjusted gross income, from Barro and Sahasakul (1983, table 2, col. 1). Values for 1981-82 are estimates based on Thompson and Hicks (1983) and Holik (1985); the value for 1983 is estimated from U.S. Internal Revenue Service (1985, table 3.4). Cols. $2-4$ : calculated with data from table 1 ; col. 5 : $\mathrm{SS}=$ col. $2+\operatorname{col} .3+$ col. 4 ; col. $6: \bar{\tau}$ $=$ col. $1+$ col. 5 .

These values are in column 6 of the table. Figure 1 shows the average marginal tax rate from the individual income tax, $\bar{T}^{\prime}$ (col. 1 of table 2 ), the overall effect from social security, SS (col. 5), and the combined average marginal tax rate, $\bar{\tau}$ (col. 6).

Consider the overall effects from the inclusion of social security, as shown in column 5 of table 2 and in figure 1 . The social security term, SS, is in the neighborhood of $1 \%$ from 1937 until 1958, reaches $2 \%$ in $1960,3 \%$ in $1966,4 \%$ in $1973,5 \%$ in $1974,6 \%$ in 1979 , and almost $7 \%$ in 1982. Thus the inclusion of this term produces a combined average marginal tax rate, $\bar{\tau}$, that rises more steeply than does the income tax rate, $\bar{T}^{\prime}$, especially since 1965 . Instead of rising from $21 \%$ in 1965 to $31 \%$ in 1981 and $27 \%$ in 1983 , we find that the $\bar{\tau}$ goes from $23 \%$ in 1965 to $38 \%$ in 1981 and $34 \%$ in 1983.

The overall effect from social security on the average marginal tax rate is always much less than the rate of employees below the ceiling, $\left(s_{f}+s_{e}\right) /\left(1+s_{f}\right)$. Primarily, this difference arises because $\Omega_{1}$-the ratio of salaries and wages below the ceiling to aggregate adjusted gross income-is much less than unity. As mentioned before, the variations in $\Omega_{1}$ derive mainly from changes in the ratio of salaries and wages below the ceiling to total salaries and wages, which appears in column 


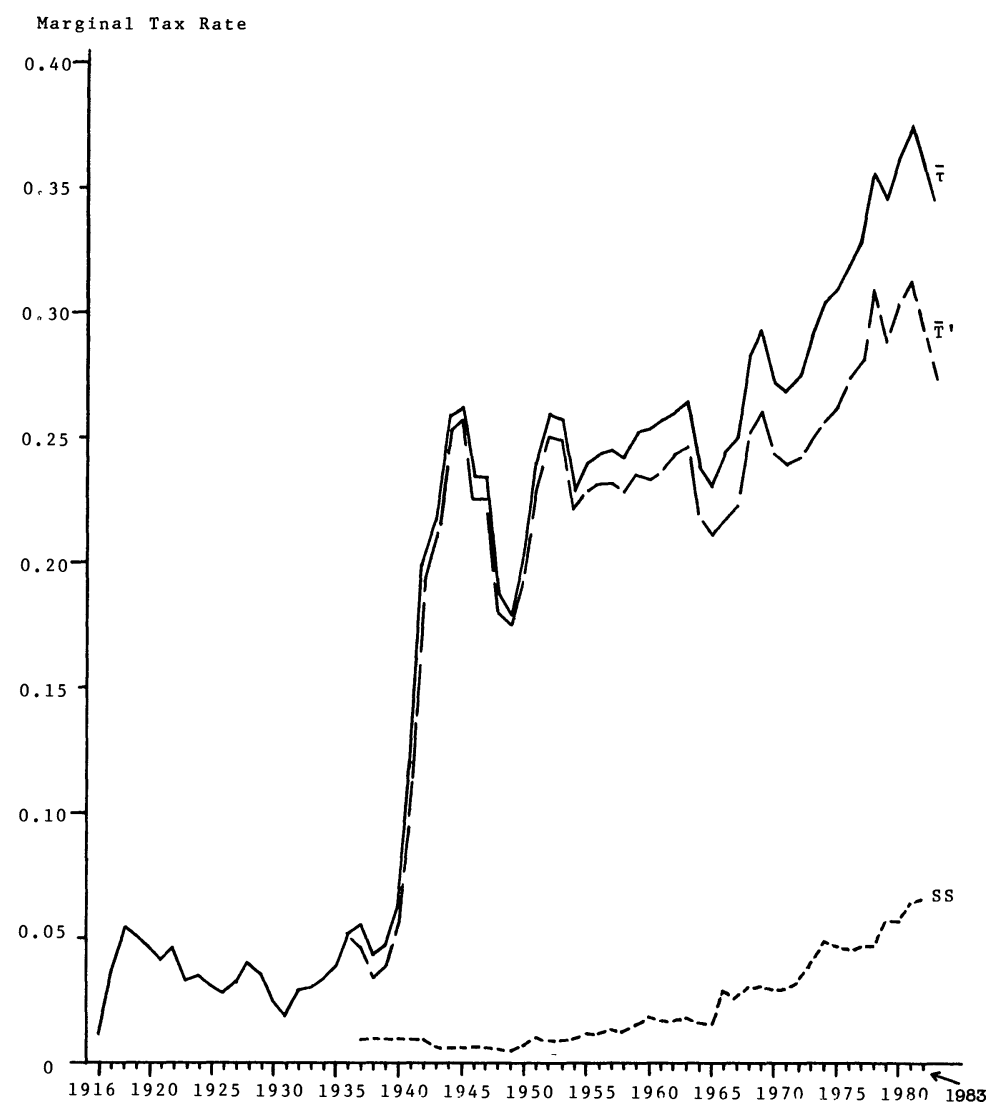

FIG. 1.-Average marginal tax rates

2 of table 1 . For example, in 1965 only $29 \%$ of total salaries and wages accrued to persons below the ceiling. If there had been no ceiling (and, unrealistically, if the rate of tax, $s_{f}=s_{e}$, were unchanged), then the overall effect of SS would have increased by a factor of 3.5, from .016 to .056 . On the other hand, the rapid increase of the ceiling in recent years has made this effect less important. In 1983, where $68 \%$ of total salaries and wages accrued to those below the ceiling, a removal of the ceiling (with contribution rates held fixed) would have raised the effect from SS by a factor of 1.5 , from .067 to .100 .

Table 3 compares the social security tax with the federal individual income tax for selected years. Notice that the ratio of revenues raised by social security to that from the income tax (shown in col. 5) rises from .07 in 1945 to .66 in 1983 .

Column 6 of the table shows a crude measure of the relative "efficiencies" of the two types of taxes. This measure is the revenue 


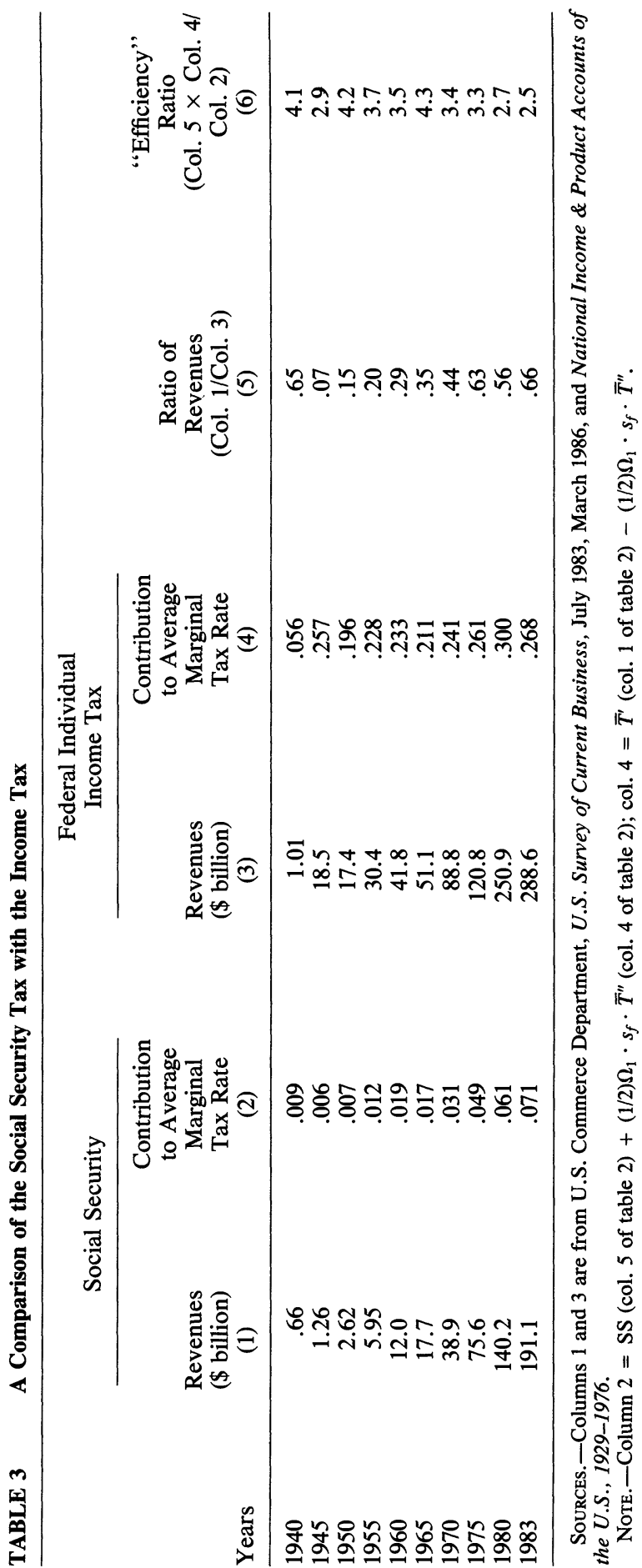


raised from social security divided by the contribution of this levy to the overall average marginal tax rate, ${ }^{7}$ expressed as a ratio to the corresponding figure for the income tax. On this basis the social security tax looks strikingly more efficient. Specifically, in 1983 the social security levy generates 2.5 times as much revenue per unit of average marginal tax rate as does the income tax, whereas in 1965 the corresponding number was 4.3. The main reason for the decline in this number since 1965 is the sharp rise in the ceiling on earnings, which has a positive effect on the average marginal tax rate from social security, relative to the revenue generated.

The social security levy turns out to be relatively "efficient" because it combines two features of a tax-rate schedule that have been stressed in the literature on optimal taxation. First, it is a flat-rate levy (on labor earnings and income from self-employment) in the range where the tax rate is positive. The shift to a flat-rate income tax has been proposed by, among others, Friedman (1962, ch. 10) and Hall and Rabushka (1983). (Surprisingly, these authors do not seem to mention that, in the social security tax, we already have a close approximation to the flat-rate income tax.) In comparison with a graduated-rate system, the flat-rate levy generates the same amount of revenues at a lower average marginal tax rate. Second, as advocated on theoretical grounds by Mirrlees (1971), the social security tax has a zero marginal rate at the top. However, as noted before, the rapid increase of the ceiling in recent years has made this feature less important than it used to be.

\section{References}

Barro, R. J., and Sahasakul, C. 1983. Measuring the average marginal tax rate from the individual income tax. Journal of Business 56 (October): 419-52.

Friedman, M. 1962. Capitalism and Freedom. Chicago: University of Chicago Press.

Gordon, R. H. 1982. Social security and labor supply incentives. NBER Working Paper no. 986. Cambridge, Mass.: NBER, September.

Hall, R. E., and Rabushka, A. 1983. Low Tax, Simple Tax, Flat Tax. New York: McGraw-Hill.

Holik, D. 1985. Individual income tax rates, 1982. Statistics of Income Bulletin 4 (Spring): 1-11.

Mirrlees, J. A. 1971. An exploration in the theory of optimum income taxation. Review of Economic Studies 38 (April): 175-208.

Thompson, R., and Hicks, C. 1983. Average and marginal tax rates, 1981 individual income tax returns. Statistics of Income Bulletin 3 (Fall): 41-49.

U.S. Internal Revenue Service. 1985. Individual Income Tax Returns, 1983. Washington, D.C.: U.S. Government Printing Office.

7. It is unclear how to allocate the cross-term, $-\Omega_{1} \cdot s_{f} \cdot \bar{T}^{\prime \prime}$ (col. 4 of table 2 ), between the two levies, although this term is quantitatively unimportant. The figures shown in table 3 allocate half of this term to each type of tax. 